\title{
Interaction of Factor VIII Antigen in Hemophilic Plasmas with Human Antibodies to Factor VIII
}

\author{
Theodore S. Zimmerman, Lynne de la Pointe, and Thomas S. Edgington \\ From the Department of Molecular Immunology, Scripps Clinic and Research Foundation, La Jolla, \\ California 92037
}

\begin{abstract}
A B S T RACT By utilizing a simple modification of previous immunological assays, we have demonstrated that most, if not all, hemophilic plasmas contain antigen reactive with human antibodies directed against Factor VIII procoagulant activity $\left(\mathrm{VIII}_{\mathrm{c}}\right)$. Antibodies developing in a nonhemophiliac patient and in a hemophiliac patient gave similar results. The VIII $_{c}$ antigen so identified was removed from hemophilic plasmas with immobilized rabbit antibody which reacted with normal VIII $\mathrm{f}_{c}$ and von Willebrand's disease antigen. These data suggest that there are greater antigenic similarities between normal and hemophilic Factor VIII than previously thought.
\end{abstract}

\section{INTRODUCTION}

Antibodies have contributed considerably to our understanding of the molecular biology of diseases associated with abnormalities of Factor VIII procoagulant activity. Heterologous antibodies raised in rabbits and goats have served to identify a protein, variably referred to as the Factor VIII-related antigen, or von Willebrand's disease antigen $\left(\mathrm{vW}_{\mathrm{Ag}}\right),{ }^{1}$ which is present in

Dr. Zimmerman is the recipient of Research Career Development Award 5 K04 HL-70242.

Received for publication 20 August 1975 and in revised form 22 December 1976.

${ }^{1}$ Abbreviations used in this paper: VIII $_{c}$ activity, Factor VIII procoagulant activity; VIII $_{c}$ antigen, Antigen which interacts with human antibody to Factor VIII (anti-VIII ( $_{c}$ ) as shown by its ability to block the $\mathrm{VIII}_{c}$ inactivating capacity of human anti-VIII antibodies. Heterologous antibodies directed against these antigens will also inactivate VIII $_{c}$ activity; von Willebrand's disease antigen (Factor VIII-related antigen; $\left.\mathrm{vW}_{\mathrm{AB}}\right)$, An antigen which precipitates with heterologous antibodies and which is decreased or absent in the plasma of most individuals with von Willebrand's disease. Though it co-purifies with $\mathrm{VIII}_{c}$ activity and $\mathrm{VIII}_{c}$ antigen under most conditions, its precise relationship to the molecule(s) expressing VIII $_{c}$ activity and/or VIII ${ }_{c}$ antigen is a subject of considerable debate at present $(11-14)$. classic hemophilia but is either decreased or virtually absent in most cases of von Willebrand's disease (1, 2). Human anti-VIII ${ }_{c}$ antibody has also been used to explore the nature of the molecular defect in hemophilia. Human anti-VIII $I_{c}$ antibodies inactivate Factor VIII procoagulant activity (VIII $)$ but, unlike heterologous antibodies, do not precipitate $\mathrm{vW}_{\mathrm{Ag}}$. Such antibodies develop in the hemophiliac after Factor VIII infusions, or more rarely, in non-hemophilic individuals without prior transfusion therapy. With one exception (3), previous studies utilizing human antiVIII $_{c}$ antibodies have detected VIII $_{c}$ antigens in only about $10 \%$ of hemophilic plasmas (4-10). We now report that such antigens can be detected in all hemophilic plasmas tested; and that these VIII $_{c}$ antigens can be removed from hemophilic plasmas by immobilized rabbit antibodies to normal human $\mathrm{VIII}_{\mathrm{c}}$ and $\mathbf{v} \mathrm{W}_{\mathbf{A g}}$.

\section{METHODS}

Preparation of immobilized rabbit antibody to $\mathrm{VIII}_{c}$ antigen and $v W_{A g}$. Rabbit antiserum to $\mathrm{VIII}_{\mathrm{c}}$ and $\mathrm{vW}_{\mathrm{Ag}}$ was prepared and adsorbed with contaminating antigens as described elsewhere $(11,15)$. After absorption the antiserum gave only one precipitin line against cryoprecipitates of normal plasma, but did not precipitate with concentrates of plasmas from individuals with severe von Willebrand's disease. Immobilized antibody was prepared by coupling ammonium sulfate precipitated globulin fractions of this antiserum (15) to Sepharose 2B agarose beads (Pharmacia Fine Chemicals Inc., Piscataway, N. J.) with cyanogen bromide as described by others (16a). These beads removed both $\mathrm{vW}_{\mathrm{Ag}}$ and $\mathrm{VIII}_{\mathrm{c}}$ activity from normal plasma but not in a stoichiometric or $1: 1$ ratio (11). Control beads were prepared by similarly coupling the globulin fractions of a pool of three normal rabbit sera to Sepharose $2 B$ beads.

Preparation of normal human $v W_{A g}$ antigen free of $\mathrm{VIII}_{c}$ activity. Plasma (acid citrate dextrose or citrate phosphate dextrose) was initially absorbed with aluminum hydroxide (Rehsorptar, Armour Pharmaceuticals Co., Chicago, Ill.) by mixing $1 \mathrm{ml}$ of aluminum hydroxide to 
$10 \mathrm{ml}$ of plasma and stirring for $15 \mathrm{~min}$ at $22-25^{\circ} \mathrm{C}$, and then removing the aluminum hydroxide by centrifugation at $15,826 \mathrm{~g}$ for $10 \mathrm{~min}$. 1 vol of absorbed plasma was mixed for $1 \mathrm{~h}$ with $10 \mathrm{vol}$ of packed QAE-Sephadex (G-50) which had been equilibrated with $0.01 \mathrm{M}$ phosphate buffer, $\mathrm{pH} 7.2$, adjusted to a conductance of 10 mmho with sodium chloride. The QAE-Sephadex was sedimented at $2,500 \mathrm{~g}$ for $10 \mathrm{~min}$ and washed twice in 10 times the volume of buffer with a conductance of $20 \mathrm{mmho}$. VIII $_{c}$ and $v W_{A g}$ were eluted from the beads by two successive washes with a volume of buffer equal to that of the QAESephadex and with a conductance of 35 mmho. Between 20 and $45 \%$ of VIII $_{c}$ and $\mathrm{wV}_{\mathrm{Ag}}$ were recovered. This material was then rendered free of VIII $_{c}$ activity, though not of VIII $_{c}$ antigen or $\mathrm{vW}_{\mathrm{Ag}}$, in the following manner. The preparations from $200 \mathrm{ml}$ of plasma were concentrated to $10 \mathrm{ml}$ in dialysis tubing against Aquacide I-A (Calbiochem), San Diego, Calif.) and were subjected to chromatography on a 2.5 $\times 90 \mathrm{~cm}$ column of $10 \%$ agarose, 200-400 mesh (Bio-Rad A-0.5 M, Bio-Rad Laboratories, Richmond, Va.) in $0.8 \mathrm{M}$ sodium chloride (13), $0.05 \mathrm{M}$ Tris ( $\mathrm{pH} 7.3$ ), $0.01 \mathrm{M}$ phenylmethylsulfonylfluoride. Over $90 \%$ of the VIII $_{c}$ was retarded by the column whereas over $90 \%$ of the $\mathrm{vW}_{\mathrm{As}}$ eluted in the void volume. All of the preceding manipulations were carried out at $22-25^{\circ} \mathrm{C}$. The void volume fractions were concentrated and rechromatographed over the same column and then stored at $-20^{\circ}$ with repeated freeze-thawing (usually six times) until no residual VIII $_{c}$ activity could be detected.

Removal of $V_{1 I I_{c}}$ antigen and $v W_{A g}$ from hemophilic plasmas by heterologous antibody beads. Hemophilic plasmas with $\mathrm{vW}_{\mathrm{Ag}}$ concentrations greater than $1.5 \mathrm{U} / \mathrm{ml}$ were incubated with an equal vol $(0.4 \mathrm{ml})$ of packed antibody beads, or control beads, for $4 \mathrm{~h}$ at $22-25^{\circ} \mathrm{C}$ with gentle rocking. The beads were removed by centrifugation at $7,000 \mathrm{~g}$ for $5 \mathrm{~min}$ in a Fisher centrifuge (Fisher Scientific Co., Pittsburgh, Pa.) and an equal volume of beads added to the supernatant plasma as before and incubated overnight with gentle rocking. The beads were again removed by centrifugation. Less than $0.03 \mathrm{vW}$ U $U / m l$ remained in the plasma after treatment by antibody beads. $\mathrm{vW}_{\mathrm{Ag}}$ concentrations in the same plasmas treated with control beads were decreased $20-40 \%$ but were still greater than $1.0 \mathrm{U} / \mathrm{ml}$ (Table V). In some of the experiments VIII $_{c}$-free $\mathrm{vW}_{\mathrm{Ag}}$ isolated from normal plasma was then added to depleted hemophilic plasma to restore the $\mathrm{vW}_{\mathrm{Ag}}$ content.

Assays of $v W_{A o}$ and VIII $_{c}$ activity. $\quad \mathrm{vW}_{\mathrm{Ag}}$ was measured by a quantitative immunoelectrophoretic technique (15). $1 \mathrm{U}$ of $\mathrm{vW}_{\mathrm{Ag}}$ was defined as that amount present in $1 \mathrm{ml}$ of a pool of plasma from 20 normal individuals (15). VIII $_{c}$ activity was determined by a partial thromboplastin time technique with plasma from individuals with severe hemophilia A (less than $1 \%$ VIII $_{c}$ ) as substrate (17).

Human antibodies to $\mathrm{VIII}_{c}$. Two antibodies were used. One had developed in a nonhemophilic woman; the other in a severe classic hemophiliac. For most experiments, the antibodies were not isolated from the plasma before use, though they were diluted 20 -fold or more in barbital buffered saline $(2.76 \mathrm{~g}$ diethyl barbituric acid, $7.3 \mathrm{~g}$ sodium chloride, and $2.07 \mathrm{~g}$ sodium barbital/liter, $\mathrm{pH}$ 7.4-7.6). Neither antibody plasma contained detectable $\mathrm{VIII}_{c}$ and at the dilution used contained less than $0.05 \mathrm{U} / \mathrm{vW}$ Ag. The first antibody was also used after it had been heated to $56^{\circ} \mathrm{C}$ for $60 \mathrm{~min}$ and isolated from plasma by ammonium sulfate precipitation (15). The hemophilic and nonhemophilic antibody preparations were used at sufficient dilution so that they introduced less than 5 or $0.5 \%$ respectively, of total $\mathrm{vW}$ Ag to the incubation mixtures. Neither antibody inactivated ristocetin cofactor activity.

\section{Blocking assay for $\mathrm{VIII}_{c}$ antigens with human anti-VIII}

Hemophilic plasmas were from unrelated donors and contained less than $1 \%$ VIII $_{\mathrm{c}}$. All were obtained at least $2 \mathrm{wk}$ after Factor VIII concentrate infusion and in some this interval was considerably greater (Table III).

Blocking step. One part of blocking material (either hemophilic plasma, hemophilic plasma depleted of $\mathrm{vW}_{\mathrm{Ag}}$ by rabbit antibody beads, $\mathrm{VIII}_{\mathrm{c}}$-free $\mathrm{vW}_{\mathrm{Ag}}$ prepared from normal plasma, or buffer as a control) was mixed with one part of human anti-VIII ${ }_{c}$. The anti-VIII ${ }_{c}$, which had been diluted to approximately $0.75 \mathrm{U} / \mathrm{ml}$ (3) so that it would inactivate only about $75-80 \%$ of the active VIII , was supplied in the second step

\section{TABLE I}

Blocking of Human, Nonhemophilic Anti-VIII c with Hemophilic Plasmas

\begin{tabular}{cccc}
\hline Subject no. & $v \mathrm{~W}_{\text {Az }}$ & $\begin{array}{c}\text { Decrease in } \\
\text { clotting time }\end{array}$ & $\begin{array}{c}\text { Increase in } \\
\text { VIII activity }\end{array}$ \\
\hline & $U / m l$ & $s$ & $U / m l$ \\
1 & 1.27 & -15.0 & +0.40 \\
2 & 1.77 & -19.1 & +0.62 \\
3 & 0.58 & -13.8 & +0.35 \\
4 & 1.11 & -15.5 & +0.52 \\
5 & 1.66 & -17.0 & +0.64 \\
6 & 0.84 & -16.6 & +0.47 \\
7 & 0.68 & -5.7 & +0.21 \\
8 & 1.50 & -16.7 & +0.45 \\
9 & 0.88 & -6.9 & +0.19 \\
10 & 1.41 & -8.1 & +0.22 \\
11 & 0.78 & -9.6 & +0.29 \\
12 & 1.61 & -6.9 & +0.21 \\
13 & 1.34 & -15.7 & +0.39 \\
14 & 0.75 & -8.8 & +0.28 \\
15 & 1.18 & -11.7 & +0.32 \\
16 & 1.25 & -14.7 & +0.29 \\
$M \pm 6$ & $1.16 \pm 0.38$ & $12.6 \pm 4.3$ & $0.37 \pm 0.14$ \\
\hline
\end{tabular}

Nonhemophilic human antibody to Factor VIII was incubated, in the first (blocking) step, with hemophilic plasma or with buffer. In the second (indicator) step, pooled diluted normal plasma was then added as a source of VIII. After a second incubation, the VIII remaining was assayed. The degree of blocking by hemophilic plasma was assessed by comparing the VIII $_{c}$ remaining when hemophilic plasma was used in the blocking step with the lesser amount of VIII ${ }_{c}$ remaining when buffer was used. In the third column, this difference is expressed as the decrease in clotting time in the VIII $_{c}$ assay. In the fourth column, this difference is expressed as the increase in VIII ${ }_{c}$ activity that this decrease in clotting time represents. Increase in VIII ${ }_{c}$ activity did not bear a constant relationship to decrease in clotting time because the assays were performed on different days utilizing different VIII $_{\mathrm{c}}$-deficient substrate plasmas with different calibration curves. Hemophilic plasmas used in these experiments were obtained at least $2 \mathrm{wk}$ after the last infusion of Factor VIII concentrate. The plasma samples from subjects no. 15 and 16 were tested after incubation with the globulin fraction of normal rabbit sera coupled to agarose beads (see Table V). 
TABLE II

Blocking of Hemophilic Anti-VIII $\mathrm{c}_{\mathrm{c}}$ with Hemophilic Plasmas

\begin{tabular}{cccc}
\hline Subject no. & $\mathrm{vW}_{\text {As }}$ & Clotting time & VIII $_{\mathrm{c}}$ \\
\hline & U/ml & $s$ & $U / m l$ \\
10 & 1.41 & -13.5 & +0.25 \\
13 & 1.36 & -11.3 & +0.19 \\
15 & 1.18 & -19.6 & +0.47 \\
\hline
\end{tabular}

The ability of hemophilic plasma to block anti-VIII ${ }_{c}$ arising in a hemophiliac was assessed as in Table I.

(see below). This was $1 / 200$ for the nonhemophilic antiVIII $_{c}$ when used in the plasma form and 1/500 after ammonium sulfate fractionation. The hemophilic antibody was diluted $1 / 20$. The mixture was incubated for $2 \mathrm{~h}$ at $37^{\circ} \mathrm{C}$. The ability of the blocking material to block the diluted anti-VIII was then assessed by adding active VIII $_{c}$ and observing the degree of subsequent inactivation.

Indicator step (inactivation of normal $\mathrm{VIII}_{c}$ ). Active $\mathrm{VIII}_{\mathrm{c}}$ was supplied in the form of a pool of 20 normal plasmas stored at $-70^{\circ} \mathrm{C}$. It was diluted 1-15 parts in barbital buffered saline and added to an equal volume of incubation mixture from the blocking step. As a control and also to provide an appropriate quantity of $\mathrm{VIII}_{c}$ for the calibration curve, the plasma pool (diluted 1/15) was also added to an equal volume of barbital buffered saline. These mixtures were then incubated for an additional $2 \mathrm{~h}$. $\mathrm{VIII}_{\mathrm{c}}$ remaining after this second 2 -h incubation was assayed in triplicate or quadruplicate in the partial thromboplastin time VIII $_{c}$ assay (17) without further dilution. The normal plasma pool, previously diluted $1 / 15$ and incubated with an equal volume of barbital buffered saline for $2 \mathrm{~h}$, was also assayed undiluted. The $\mathrm{VIII}_{\mathrm{c}}$ present was assigned the value of $1 \mathrm{U} / \mathrm{ml}$. Serial dilutions of this standard were used to construct the VIII $_{c}$ calibration curve. The blocking assay was performed in duplicate for each plasma tested and the results averaged. Deviation between duplicates was routinely less than 1-3 s. If the discrepancy was greater, the assay was

TABLE III

Blocking of Human, Nonhemophilic Anti-VIII c with Hemophilic Plasmas Obtained after Prolonged Infusion-Free Periods

\begin{tabular}{ccccc}
\hline Subject no. & $\begin{array}{c}\text { Days } \\
\text { postinfusion }\end{array}$ & $\mathrm{vW}_{\mathrm{As}}$ & $\begin{array}{c}\text { Decrease in } \\
\text { clotting time }\end{array}$ & $\begin{array}{c}\text { Increase in } \\
\text { VIII activity }\end{array}$ \\
\hline & & $U / m l$ & $s$ & U/ml \\
12 & 56 & 1.61 & -5.5 & +0.20 \\
12 & 63 & 1.61 & -6.9 & +0.21 \\
13 & 28 & 1.95 & -13.7 & +0.24 \\
13 & 58 & 1.32 & -11.9 & +0.16 \\
13 & 72 & 1.79 & -13.1 & +0.28 \\
13 & 79 & 1.36 & -15.7 & +0.39 \\
14 & 78 & 0.75 & -8.8 & +0.28 \\
\hline
\end{tabular}

Plasma samples were obtained at the indicated intervals following infusion of Factor VIII concentrates. The degree of blocking was assessed as for Table I. repeated. The degree of blocking was assessed by comparing the quantities of VIII $_{c}$ remaining at the end of the second incubation. If a hemophilic plasma (or other blocking material) had blocked the anti-VIII ${ }_{c}$, then more VIII $_{c}$ remained after the final incubation than if buffer had been used instead of blocking material. This increase in residual VIII $_{c}$ seen when blocking occurred is reported as both the decrease in clotting time (seconds) observed in the VIII $_{c}$ assay and the increase in units/milliliter of VIII ${ }_{c}$ that this decrease in clotting time represents (see Tables).

\section{RESULTS}

Each of the 16 hemophilic plasmas tested blocked the capacity of nonhemophilic human anti-VIII ${ }_{c}$ antibody to inactivate VIII $_{c}$ of normal plasma (Table I). Three of these plasmas were also tested with human antibody which had arisen in a hemophiliac and similar results were obtained (Table II). All of the plasmas tested were obtained at least $2 \mathrm{wk}$ after the last infusion of Factor VIII concentrate. However, some were obtained after infusion-free periods of up to 79 days. Based on the $t-1 / 2$ of $20-40 \mathrm{~h}$ of $\mathrm{vW}_{\mathrm{Ag}}$ observed by Bennett and Ratnoff (18) less than $5.4 \times 10^{-13} \%$ of the material infused would have been remaining after this time. Yet, no significant difference in blocking by plasmas obtained after these prolonged infusionfree periods was seen as compared to plasmas obtained after much shorter infusion-free periods (Table III). Thus, it is unlikely that infused Factor VIII can account for the blocking. Antibody separated from plasma by ammonium sulfate precipitation gave results similar to those obtained when antibody in diluted plasma was used (Table IV).

Blocking in this system is determined by assaying the VIII $_{c}$ activity remaining at the end of the indicator step incubation. If VIII $_{c}$ antigen is present in the blocking step then less antibody is free to inactivate the VIII $_{c}$ of the pooled normal plasma supplied in the indicator step. This is reflected as a shortened clotting

\section{TABLE IV}

Comparison of Blocking of Plasma Nonhemophilic Anti-VIII $I_{\mathrm{c}}$ and Ammonium Sulfate Precipitated Anti-VIII

\begin{tabular}{|c|c|c|c|}
\hline Subject no. & $v W_{A B}$ & $\begin{array}{l}\text { Decrease in } \\
\text { clotting time }\end{array}$ & $\begin{array}{l}\text { Increase in } \\
\text { VIII }_{\mathrm{c}} \text { activity }\end{array}$ \\
\hline & $U / m l$ & $s$ & $U / m l$ \\
\hline & \multicolumn{3}{|c|}{ Plasma anti-VIII ${ }_{c}$ (diluted 1:200) } \\
\hline 14 & 0.78 & -9.2 & +0.23 \\
\hline
\end{tabular}

Ammonium sulfate precipitated anti-VIII ${ }_{\mathrm{c}}$ (diluted 1:500)

14

0.78

$-10.6$ $+0.28$

Blocking of these two different preparations of the same antibody was assessed as for Table I. 
TABLE V

Depletion of $v W_{\mathrm{Ag}}$ from Hemophilic Plasmas: Effect on Blocking of Nonhemophilic Anti-VIII $\mathrm{c}_{\mathrm{c}}$

\begin{tabular}{lrcc}
\hline \multicolumn{1}{c}{ Subject no. } & $\mathrm{vW}_{\mathrm{As}}$ & Clotting time & VIII activity \\
\hline & \multicolumn{1}{c}{$\mathrm{U} / \mathrm{ml}$} & \multicolumn{1}{c}{$s$} & $\mathrm{U} / \mathrm{ml}$ \\
15 (control) & 1.18 & -11.7 & +0.32 \\
15 (depleted) & $<0.03$ & -1.9 & +0.03 \\
16 (control) & 1.25 & -14.7 & +0.29 \\
16 (depleted) & $<0.03$ & -1.3 & +0.02 \\
\hline
\end{tabular}

Hemophilic plasmas were depleted of $\mathrm{vW}_{\mathrm{Ag}}$ by incubation with rabbit anti-VIII ${ }_{\mathrm{c}}$-anti-vW $\mathrm{W}_{\mathrm{Ag}}$ which had been coupled to agarose beads (see Methods). As a control, the hemophilic plasma was incubated with the globulin fraction of normal rabbit serum which had been similarly coupled to agarose beads. $\mathrm{vW}_{\mathrm{Ag}}$ concentration indicated is that after incubation with control or antibody beads. The ability of these plasmas to block human nonhemophilic anti-VIII ${ }_{c}$ was then evaluated as for Table I.

time in the VIII $_{c}$ partial thromboplastin time assay. To rule out nonspecific clotting time shortening due to the relatively concentrated hemophilic plasma used in the first step (hemophilic plasma:normal plasma pool ratio $=7.5: 1$ ) three additional experiments were performed. First, hemophilic plasma was incubated with immobilized rabbit antibody to $\mathrm{vW}_{\mathrm{Ag}}$ and VIII (Table V). This removed most of the $\mathrm{vW}_{\mathrm{Ag}}$ (residual concentrations less than $0.03 \mathrm{U} / \mathrm{ml}$ ). The capacity of the hemophilic plasma to block human anti-VIII ${ }_{c}$ was also removed. However, nonimmune immobilized rabbit globulin did not remove the capacity of these same hemophilic plasmas to block. Thus the shortened clotting time in the VIII $\mathrm{C}_{c}$ assay of the indicator step is directly related to material removed by the rabbit antibody and not to a nonspecific quality of the hemophilic plasma used for blocking. In addition, repletion of the hemophilic plasma with $\mathrm{vW}_{\mathrm{Ag}}$ isolated from normal human plasmabut rendered free of $\mathrm{VIII}_{c}$ activity - restored the ability of the $\mathrm{vW}_{\mathrm{Ag}}$ depleted hemophilic plasma to block the human antibody (Figs. 1 and 2). This antigenic material blocked the human antibody comparably to hemophilic plasmas containing similar amounts of $\mathrm{vW}_{\mathrm{Ag}}$.

Secondly, the hemophilic plasmas to be tested were mixed with an equal amount of buffer instead of antibody, incubated for $2 \mathrm{~h}$, then incubated for $2 \mathrm{~h}$ with an equal volume of buffer instead of diluted plasma pool. This mixture was then assayed in the partial thromboplastin time VIII $_{c}$ assay to see if the hemophilic plasmas alone could shorten the clotting time of the substrate plasma and thus give a false impression of blocking. Most hemophilic plasma tested had no effect on the assay clotting time as compared to that seen when buffer alone was assayed. Some plasmas lengthened the clotting time up to 5-8 s. An occasional plasma shortened the clotting time up to $5 \mathrm{~s}$. Shortening of $5 \mathrm{~s}$ in this portion of the VIII $_{c}$ calibration curve amounted to less than $0.01 \mathrm{U} / \mathrm{ml} \mathrm{VIII}_{\mathrm{c}}$ activity. Though this was considerably less than the average of $0.37 \mathrm{U} / \mathrm{ml}$ increase in VIII $_{c}$ activity seen in the blocking experiments, these plasmas were nevertheless excluded from the study.

Thirdly, hemophilic plasma was mixed with an equal volume of antibody, incubated $2 \mathrm{~h}$, and then mixed with an equal volume of buffer instead of diluted normal plasma. This mixture was then incubated an additional $2 \mathrm{~h}$ and assayed in the partial thromboplastin time assay. The clotting time was unchanged for that seen when buffer alone was assayed in the partial thromboplastin time assay.

The reproducibility of the blocking assay was assessed by re-assaying samples of plasma from patient no. 10 on eight occasions over a 2-mo period. Blocking, as judged by a decrease in clotting time in the VIII $_{c}$ assay averaged $8.1 \mathrm{~s}$ with a SD of $2.3 \mathrm{~s}$ and a range of 5.5-12 s. The corresponding increase in $\mathrm{VIII}_{\mathrm{c}}$ activity averaged $0.22 \mathrm{U} / \mathrm{ml}$ with a $\mathrm{SD}$ of 0.06 $\mathrm{U} / \mathrm{ml}$ and a range of $0.13-0.33 \mathrm{U} / \mathrm{ml}$.

\section{DISCUSSION}

These studies demonstrate that most, if not all, hemophilic plasmas contain antigens capable of interacting with and neutralizing human antibodies to $\operatorname{VIII}_{c}$. These findings contrast with previous studies (4-10) in which such antigens could only be detected in approximately $10 \%$ of hemophilic plasmas. In one previous study - that of Biggs-VIII ${ }_{c}$ antigens could be detected in all hemophilic plasmas tested but only at

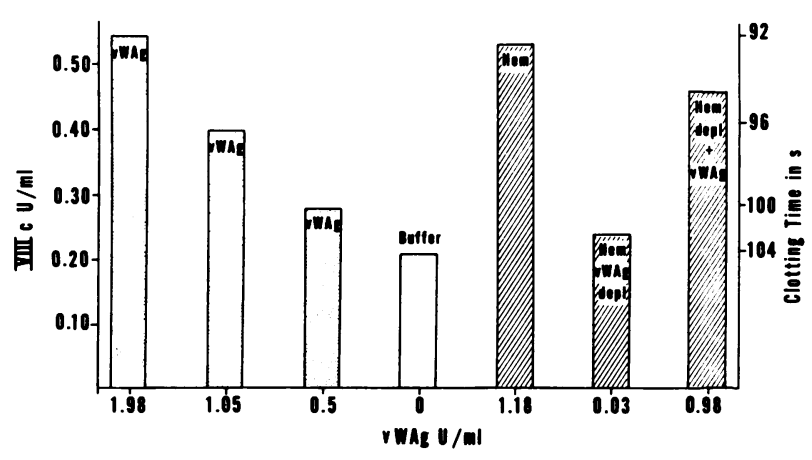

FIGURE 1 Comparison of blocking capacity of $\mathrm{vW}$ Ag antigen isolated from normal human plasma (and freed of $\mathrm{VIII}_{c}$ activity-see Methods) with hemophilic plasma, hemophilic plasma depleted of $\mathrm{vW}_{\mathrm{Ag}}$ by immobilized antibody, and depleted hemophilic plasma repleted with $\mathrm{vW}_{\mathrm{Ag}}$ antigen isolated from normal human plasma. Factor VIII activity remaining in the indicator step of the assay is indicated on the left vertical axis and the corresponding clotting times on the right vertical axis. The $\mathrm{vW}_{\mathrm{Ag}}$ content of blocking materials is indicated on the horizontal axis. 


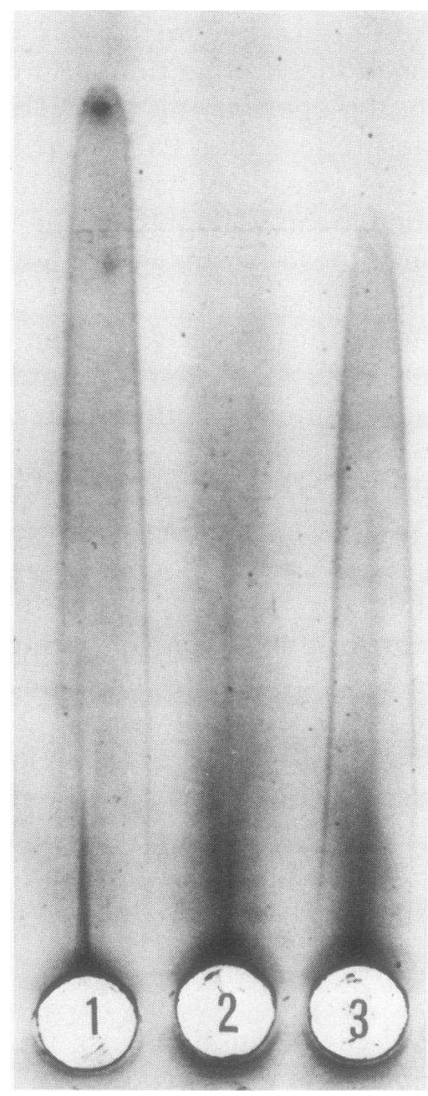

FIGURE 2 Quantitative immunoelectrophoretic measurement of $\mathrm{vW}_{\mathrm{Ag}}$ in hemophilic plasmas before (well no. 1) and after depletion (well no. 2) of $\mathrm{vW}_{\mathrm{Ag}}$ by immobilized antibody and following repletion with $\mathrm{vW}$ Ag isolated from normal plasma (well no. 3). The height of the rockets are proportional to $\mathrm{vW}$ Ag content.

concentrations of antibody greater than $2.0 \mathrm{U} / \mathrm{ml}(3)$. At concentrations of antibody less than this VIII $_{c}$ antigens were detected only in a minority of plasmas. In the studies reported here, however, antibody concentrations of $0.75 \mathrm{U} / \mathrm{ml}$ were effective in this regard.

The reason for the differences between the previously reported work and our study may reflect modifications we have introduced into the assay procedure. In these experiments, VIII $_{c}$ activity carry over was eliminated by introducing VIII $_{c}$ activity into the assay only in the second, i.e., indicator, step and then in small amounts ( $1: 15$ dilution of a normal plasma pool). Only small amounts of anti-VIII $I_{c}$ antibody were required to inactivate $75-80 \%$ of the VIII $_{c}$ activity in this diluted normal plasma pool. Thus the ratio of the blocking antigen (hemophilic plasma, etc.) to antibody could be kept relatively high without concentrating the plasmas to be tested. However, this modification of the assay prevents direct comparison of the blocking capacity of normal plasma with hemophilic plasma because the blocking antigen cannot have detectable VIII $_{c}$ activity.

Blocking of anti-VIII ${ }_{c}$ cannot be attributed to nonspecific effects resulting from the relatively high ratio of blocking plasma to antibody. This was shown by removing the blocking capacity of the plasma with immobilized rabbit antibody directed against $\mathrm{vW}_{\mathrm{AB}}$ and VIII $_{c}$. Plasmas similarly treated with nonimmune immobilized rabbit globulin were not depleted of the capacity to block in the assay. In addition, the high concentrations of blocking plasma used were shown to have no significant influence on the VIII $_{c}$ assay.

We have previously shown that our rabbit antibody to $\mathrm{vW}_{\mathrm{Ag}}$ removes both this antigen and $\mathrm{VIII}_{\mathrm{c}}$ activity from normal human plasma though it does not do so in a stoichiometric 1:1 ratio (11). $\mathrm{vW}_{\mathrm{Ag}}$ isolated from normal plasma and rendered free of $\mathrm{VIII}_{\mathrm{c}}$ procoagulant activity by gel filtration in $0.8 \mathrm{M} \mathrm{NaCl}$ and by repeated freeze thawing appeared to retain VIII $_{c}$ antigens since it blocked human antibodies in a fashion similar to hemophilic plasmas containing comparable amounts of $\mathrm{vW}_{\mathrm{Ag}}$. Previous studies have also shown blocking of human anti-VIII $\mathrm{C}_{\mathrm{c}}$ antibody with $\mathrm{vW}_{\mathrm{Ag}}$ freed of VIII $_{\mathrm{c}}$ activity (19). Whether both VIII $_{c}$ antigen and $\mathrm{vW}_{\mathrm{Ag}}$ reside on the same molecule or on molecules which co-purify is a source of continuing debate.

These findings have implications for the molecular nature of the abnormality giving rise to hemophilia A as well as to the development of anti-VIII ${ }_{c}$ antibodies in individuals with this disease. They suggest that antigenic differences between normal VIII $_{c}$ and the form of VIII $_{c}$ present in hemophilic plasma may be less marked than previously supposed. The presence of these VIII $_{c}$ antigens in all severe hemophiliacs tested may explain the relatively low incidence $(8-14 \%)(20)$ of anti-VIII ${ }_{c}$ antibodies developing in these individuals in spite of repeated transfusion therapy with active Factor VIII preparations.

\section{ACKNOWLEDGMENTS}

This work is publication no. 1021 from the Scripps Clinic and Research Foundation and was supported by U. S. Public Health Service grants HL-15491 and HL-16411.

\section{REFERENCES}

1. Stites, D. P., E. J. Hershgold, J. D. Perlman, and H. H. Fudenberg. 1971. Factor VIII detection by hemagglutination inhibition: Hemophilia A and von Willebrand's disease. Science (Wash. D. C.). 171: 196-197.

2. Zimmerman, T. S., O. D. Ratnoff, and A. E. Powell. 1971. Immunologic differentiation of classic hemophilia (Factor VIII deficiency) and von Willebrand's disease. With observations on combined deficiencies of anti-hemophilic factor and proaccelerin (factor V) and on an acquired circulating anticoagulant against antihemophilic factor. J. Clin. Invest. 50: 244-254. 
3. Biggs, R. 1974. The absorption of human Factor VIII neutralizing antibody by Factor VIII. Br. J. Haematol. 26: 259-267.

4. Abildgaard, C. F., J. Vanderheiden, A. Lindley, and F. Rickles. 1967. Studies of cross-reactivity of acquired Factor VIII inhibitor activity in hemophilic plasma. Thromb. Diath. Haemorrh. 18: 354-363.

5. Feinstein, D., M. N. Y. Chong, C. K. Kasper, and S. I. Rapaport. 1969. Hemophilia A: Polymorphism detectable by a factor VIII antibody. Science (Wash. D. C.). 163: 1071-1072.

6. Hoyer, L. W., and R. T. Breckenridge. 1968. Immunologic studies of antihemophilic factor (AHF, Factor VIII): Cross-reacting material in a genetic variant of hemophilia A. Blood. 32: 962-971.

7. Denson, K. W. E., R. Biggs, M. E. Haddon, R. Borrett, and K. Cobb. 1969. Two types of haemophilia $\left(\mathrm{A}^{+}\right.$and $\left.\mathrm{A}^{-}\right)$: A study of 48 cases. Br. J. Haematol. 17: 163-171.

8. Meyer, D., and M. J. Larrieu. 1971. Factor VIII and IX variants. Relationship between haemophilia $B_{m}$ and haemophilia B+. Eur. J. Clin. Invest. 1: 425-431.

9. Lechner, K. 1972. Inactive Factor VIII in hemophilia $A$ and Willebrand's disease. A study of 117 cases. Acta Haematol. (Basel). 48: 257-268.

10. Holmberg, L., and I. M. Nilsson. 1973. Immunologic studies in haemophilia A. Scand. J. Haematol. 10: 12-16.

11. Zimmerman, T. S., and T. S. Edgington. 1973. Factor VIII coagulant activity and Factor VIII-like antigen: Independent molecular entities. J. Exp. Med. 138: 10151020.

12. Owen, W. G., and R. H. Wagner. 1972. Antihemophilic factor: Separation of an active fragment following dissociation by salts or detergents. Thromb. Diath. Haemorrh. 27: 502-515.
13. Weiss, H. J., and L. W. Hoyer. 1973. Von Willebrand factor: Dissociation from antihemophilic factor procoagulant activity. Science (Wash. D. C.). 182: 1149-1151.

14. Switzer, M. E., and P. A. McKee. 1976. Studies on human antihemophilic factor. Evidence for a covalently linked subunit structure. J. Clin. Invest. 57: 925-937.

15. Zimmerman, T. S., L. W. Hoyer, L. Dickson, and T. S. Edgington. 1975. Determination of the von Willebrand's disease antigen (Factor VIII-related antigen) in plasma by quantitative immunoelectrophoresis. J. Lab. Clin. Med. 86: 152-159.

16. Cuatrecasas, P., M. Wilchek, and C. B. Anfinsen. 1968. Selective enzyme purification by affinity chromatography. Proc. Natl. Acad. Sci. U. S. A. 61: 636-643.

17. Ratnoff, O. D., R. E. Botti, R. T. Breckenridge, and A. S. Littell. 1964. Some problems in the measurement of antihemophilic factor. In The Hemophilias, International Conference on Hemophilia, Washington, D. C. K. M. Brinkhouse, editor. The University of North Carolina Press, Chapel Hill, N. C. 3-10.

18. Bennett, B., and O. D. Ratnoff. 1972. Studies on the response of patients with classic hemophilia to transfusion with concentrates of antihemophilic factor. A difference in the half-life of antihemophilic factor as measured by procoagulant and immunologic techniques. J. Clin. Invest. 51: 2593-2596.

19. Rick, M. E., and L. W. Hoyer. 1973. Immunologic studies of antihemophilic factor (AHF, Factor VIII). V. Immunologic properties of AHF subunits produced by salt dissociation. Blood. 42: 737-747.

20. Shapiro, S. S., and M. Hultin. 1975. Acquired inhibitors to the blood coagulation factors. Seminars in Thrombosis and Hemostasis. 1: 336-385. 